Keio J. Med. 23: 1-15, 1974

\title{
THE STUDIES OF CELLULAR IMMUNITY TO GYNECOLOGIC TUMORS WITH MACROPHAGE MIGRATION INHIBITION TEST
}

\author{
TAKIKO KENJO \\ Department of Obstetrics and Gynecology, School of Medicine, \\ Keio University, Tokyo, Japan
}

(Received for publication February 19, 1974)

\begin{abstract}
It has been recognized that macrophage migration inhibition test (MIT) would duly reflect various phases of cellular immunity in vitro, including delayed hypersensitivity, transplantation and anti-tumor immunity. The studies of cell-mediated immunity have been undertaken in vitro by the MIT on 73 patients with operable gynecologic tumor and on 10 mice bearing uterine tumor induced by 20-methylcholanthrene.

Eighty-six per cent of 29 patients with malignant tumors-choriocarcinoma, ovarian cancer and carcinoma of the uterine cervix and corpus-revealed positive migration inhibitory activity immediately after extirpation of pathology. On the contrary, all of the cases with benign tumor revealed negative reaction.

Out of 16 positive patients who were able to be followed, 12 cases received complete removal of pathology and disclosed negative reaction 35 to 60 days after the initial test. The reaction of four patients with wide-spread metastasis remained positive for more than 3 months after surgery.

Besides, the migration inhibitory activity were detected in only one out of 5 cases with invasive mole and 11 out of 33 patients with hydatidiform mole.

In addition, the positive reaction on MIT was presented in $90 \%$ of the mice bearing uterine tumor and cross reaction was also observed in some cases.
\end{abstract}

\section{INTRODUCTION}

In the past decades, significant evidence for the existence of tumor specific transplantation antigen (TSTA) has been developed. ${ }^{1}$ Moreover, it has been demonstrated by several investigations that the antigen contained in tumor cells is different from a recognizable one in normal condition and the altered antigen 
state gives rise to an immune respons which results in the rejection of the tumor. ${ }^{2,3,4}$

Although humoral antibodies have been shown to be involved in rejection of certain animal tumors, ${ }^{5}$ most experimental studies involving the host defence against tumor have revealed the importance of cellular immunity similar to homograft rejection, possible delayed hypersensitivity. $6,7,8,9$

Taken from several methods available for detecting, in vitro, the presence of cellular immunity in men and animals bearing tumors, the following important advances of cell-mediated immunity in the tumor have been in research: the results prove that sensitized and activated lymphocytes produce factors which affect the activity of macrophage and the other that stimulated lymphocytes are directly cytotoxic for target cells.

The method represented in the former is macrophage migration inhibition test and in the latter colony inhibition test.10,11

Macrophage migration inhibition test (MIT) was first introduced by George and Vaughan and has been extensively investigated by David et al12 and by Bloom and Bennett. ${ }^{13,14}$

It has been recognized that this method would duly reflect various phases of cellular immunity in vitro, including delayed-type hypersensitivity, transplantation and anti-tumor immunity. Many investigators have corrovorated in the inhibition of migration in vitro was not directly mediated by serum factor, but resulted from an interaction between sensitive cells and respective antigens. Furthermore, it has been confirmed that when sensitized lymphocytes contact with specific antigen, they release in vitro a soluble substance into supernatant and the subject inhibits the migration of normal macrophage. This substance has been called macrophage migration inhibitory factor (MIF).

In addition, several studies have revealed that when lymphocytes from suitably sensitized animals or men are stimulated by sensitizing antigen, they produce several soluble substances with different biological activities except migration inhibitory factor, including lymphotoxic, chemotactic, mitogenic, skin reactive and interferon like factor. ${ }^{15,16,17,18}$

Although its exact chemical nature is undetermined, Remold et al using sucrose gradient centrifugation, found that MIF sedimented less rapidly than albumin and presented evidence that MIF may have a glycoprotein.19 According to other authors, MIF has also been shown to be a protein and whose formation is inhibited by promycin and not by RNAase or DNAase.

The sensitized lymphocytes are specifically reactive cells and normal macrophages serve as indicator in this technique. ${ }^{20}$ Recent studies indicated that macrophage migration inhibition test has been successfully studied cell-mediated 
immunity against the tumor specific antigens in many animal tumors induced by chemical carcinogens. ${ }^{21,22}$

In the present report, MIT was applied in the research of the cellular immunity to gynecologic tumors.

\section{MATERIALS AND METHODS}

Patients: Twenty-five patients undergoing surgery for variety of malignant tumors, including 8 chorioepitheliomas, 5 ovarian cancers and 12 carcinomas of the uterine cervix and corpus, and five patients with benign tumors, were tested.

Thirty-eight patients with hydatidiform mole and invasive mole were similary investigated.

Mice: The female I.C.R. mice bearing uterine tumors induced by 20 -methylcholanthrene, as will be mentioned in the following paragraph, were used.

Carcinogen and method of its application:

Twenty-methylcholanthrene was used throughout this study as a carcinogen. Three month-old female mice of inbred strain I.C.R. were employed at the time of experiment. With the use of a technique suggested by Murphy, ${ }^{23}$ the mice were exposed to cotton strings inpregnated with 20-methylcholanthrene mixed beeswax, inserted into their uterine cavities or cervix canals. The duration of exposure was 4 to 12 months.

The mice were subjected for MIT, when they have had a large palpable pelvic mass.

Experimental method of macrophage migration inhibition test:

This tests were carried out using the technique described by George and Vaughan, slightly modified.

Preparation of tumor antigen:-At the start, a piece of tissue weighing more than one gram was removed from the deeper part of fresh tumor which has been eliminated during operation.

The specimen which was cut into fine sections, was suspended in Hanks solution with antibiotics. The resulting material was then subjected to sonic disintegration for $3 \mathrm{~min}$ and centrifuged at $850 \mathrm{rpm}$ for $5 \mathrm{~min}$.

The supernatant was separated and its protein concentration estimated by spectrophotometry. The supernatant thus obtained was used as a crude antigen.

Preparation of lymphoid cell suspension:-In tumor bearing mice, the lymphocytes were harvested from the mesentric lymphnodes or spleens.

The lymphnode or spleen was diced in Hanks solution with lactalbumin and teased gently. The freed materials were filtered through nylon mesh to remove 
large pieces and the resulting suspensions placed in conical tubes centrifuged at $850 \mathrm{rpm}$ for $5 \mathrm{~min}$. The lymphocytes obtained were suspended in complete medium (Hanks solution containing $20 \%$ calf serum, lactalbumin and antibiotics) and recorded with hemocytometer.

In patients, the lymphocytes were taken from peripheral blood in the individuals with gynecologic tumors. Ten milliliters of the peripheral venous blood heparinized were mixed with $3 \mathrm{ml}$ of $3 \%$ gelatin fluid. After sedimenting for $30 \mathrm{~min}$ at $37^{\circ} \mathrm{C}$, the leucocyte rich plasma was removed and centrifuged at $850 \mathrm{rpm}$ for $5 \mathrm{~min}$.

The lymphocytes were separated from the leucocyte suspension by filtration through a tetron fiber column and was suspended in the medium after having been washed twice. Approximately one million of lymphocytes were recovered and the majority of the lymphocytes $(90 \%)$ were vital as determined by trypan blue exclusion.

Preparation of guinea pigs peritoneal exudate suspension: - Peritoneal exudate suspension were induced by washing out the peritoneal cavities of normal guinea pigs to which paraffin oil was injected 4 days before this test was performed.

The exudate was separated from the oil by centrifugation at $850 \mathrm{rpm}$ for 5 min washed twice with medium and added up to 10 per cent. The majority of the collected cells was macrophages, but a small number of lymphocytes was also consistently presented, as determined by morphology.

Viability of the exudate as measured by dye exclusion was over 90 per cent.

For each experiment, macrophages and lymphocytes were prepared separately, as previously described.

The cells population were adjusted to contain the following mixtures:Eighty per cent macrophages and $20 \%$ lymphocytes. The mixtures were drawn up into capillary tubes which were sealed at one end by heating and at same time, macrophages were also drawn up into capillary tubes. At least 4 capillary tubes were used to determine the average migration area for each test situation. The tubes were then centrifuged at $1000 \mathrm{rpm}$ for $5 \mathrm{~min}$.

Following centrifugation the tubes were cut at the cell-liquid interface and the portions containing the cells were anchored with silicon grease to the bottom cover slip of a migration chamber (two capillaries per chamber). For the tissue culture in this test, the following medium was prepared, namely Hanks solution with lactalbumin containing $20 \%$ calf serum, 100 unit per milliliter penicillin, 100 microgram per milliliter streptomycin $(\mathrm{pH} 7.2)$. The medium with or without antigen was added to the chambers and the cover slips were put on them.

The final concentration of tumor antigen was laid in the range 70 to 250 
$\mu \mathrm{g} / \mathrm{ml}$ protein. These chambers were then incubated at $37^{\circ} \mathrm{C}$ in $5 \%$ Co2 atmosphere for 48 hours and the area of macrophage migration from the capillary tubes was measured with a micrometer scale under the microscope.

The average area of cell migration for each preparation, based on four capillaries, was used to calculate the migration index and the percentage of modified migration index (m. M.I \%) advocated by Akiyama et al as follows.

$\mathrm{M} . \mathrm{I}=\frac{\text { average area of migration with antigen }}{\text { average area of migration without antigen }}$

$\mathrm{X}=\mathrm{M} . \mathrm{I}$ in mixed cells

$\mathrm{Y}=\mathrm{M} . \mathrm{I}$ in macrophages alone

m. M.I $(\%)=(\mathrm{X}-\mathrm{Y}+1) \times 100$.

In this experiment, a value of less than 75 per cent of modified migration index indicated migration inhibition of macrophage induced by antigen and this was expressed as positive migration inhibition.

\section{RESULTS}

Experimental uterine tumors in mice and migration inhibitory activity in mice bearing chemically induced tumors:

An attempt was made to produce experimental tumors in the uterus of mice. Ten out of 68 mice consequently developed uterine tumors visible at 4 to 12 months after carcinogenic treatment.

The largest of these tumors compressing the intestinal canal, the bladder and the rectum, was $4 \mathrm{~cm}$ in diameter and the average mass was about $2.1 \mathrm{~cm}$. Although the invasion into parametrial tissues were detected in some instances, no metastasis was demonstrated in any of the mice. The tumors were removed surgically from the mice for MIT.

The center of the masses were composed of soft caseous material, the peripheral regions were usually firm and some animals developed pyometria. The histological examination of the tumors was observed various types of uterine tumor, for example, sarcoma, adenocarcinomas, adenoacanthoma and squamous cell carcinomas of uterus. One out of 10 mice in which there were clinical evidence of an abdominal mass had died immediately before MIT was examined.

In these mice, MIT have been examined with autochthonous or syngeneic tumor antigens. Migration inhibitory activity has been detected in 9 out of 10 attempts when the results were tested with autochthonous tumor antigen immediately after removal of pathology. As shown in Table 1, the modified migration indices in the positive observation varied widely from 7 to 66 per cent 


\section{Table 1}

Macrophage migration inhibition test in mice bearing uterine tumors induced by methylcholanthrene

\begin{tabular}{c|c|c|c}
\hline Cases & $\begin{array}{c}\text { Tumor size } \\
\text { (cm) }\end{array}$ & $\begin{array}{c}\text { Exposure period } \\
\text { (month) }\end{array}$ & m. M. I (\%) \\
\hline No. 1 & 3.0 & 6 & 19 \\
No. 2 & 2.0 & 6 & 28 \\
No. 3 & 3.0 & 6 & 13 \\
No. 4 & 2.5 & 6 & 41 \\
No. 5 & 2.0 & 6 & 7 \\
A-1 & 1.0 & 4 & 89 \\
A-2 & 1.3 & 10 & 66 \\
B-1 & 0.8 & 4 & 44 \\
E-1 & 4.0 & 5 & 35 \\
E-2 & 1.0 & 12 & 54 \\
\hline
\end{tabular}

and there was $85 \%$ in an animal who died (A-2).

In addition, positive migration inhibitory activity were also present in some cases where syngeneic tumor antigens were used and cross reactions were observed in syngeneic system. Fig. 1 demonstrates graphically two typical ex-

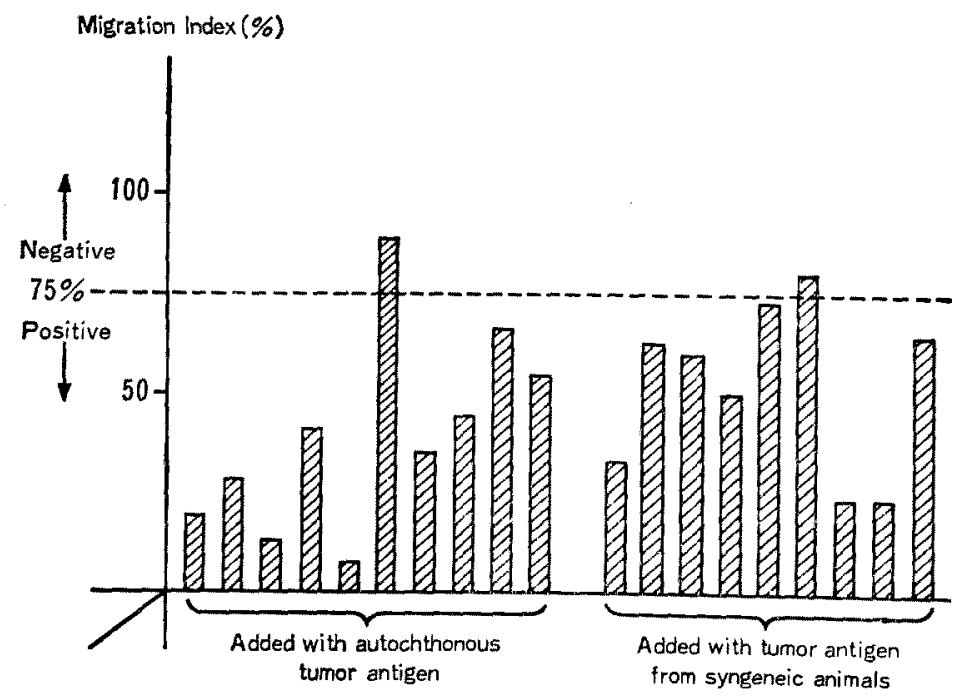

Fig. 1. The grade of migration of macrophage in mice bearing uterine tumors induced by 20-methylcholanthrene. 
periments with autochthonous and syngeneic tumor antigen. Modified migration index with autochthonous and syngeneic tumor antigen was $39.6 \pm 24.9$ and $52.4 \pm 19.7$ respectively.

These results can be interpreted as indicating the existence of tumor specific antigen in experimental uterine tumors or of cross reactive antigen in syngeneic tumor bearing mice.

Clinical application of MIT:

Migration inhibition test was performed during some periods after opera-

Table 2

Result of migration inhibition test in patients with ovarian cancer, carcinoma of uterine cervix and endometrial cancer after operation

\begin{tabular}{|c|c|c|c|c|c|}
\hline \multirow[t]{8}{*}{ Patient } & Tumor type & $\begin{array}{l}\text { Time after } \\
\text { operation } \\
\text { (days) }\end{array}$ & $\begin{array}{l}\text { Migration } \\
\text { index with } \\
\text { autochthon- } \\
\text { ous tumor } \\
(\%)\end{array}$ & Reaction & $\begin{array}{l}\text { Migration } \\
\text { index with } \\
\text { allogeneic } \\
\text { tumor } \\
(\%)\end{array}$ \\
\hline & \multirow{7}{*}{$\begin{array}{l}\text { Ovarial } \\
\text { carcinoma }\end{array}$} & 2 & 49 & + & \multirow{7}{*}{$\begin{array}{l}T \cdot H_{1}(88) \\
S \cdot M(105)\end{array}$} \\
\hline & & 34 & 33 & + & \\
\hline & & 2 & 50 & + & \\
\hline & & $\begin{array}{l}32 \\
62\end{array}$ & $\begin{array}{r}10 \\
114\end{array}$ & \pm & \\
\hline & & $\begin{array}{r}2 \\
15\end{array}$ & $\begin{array}{r}32 \\
101\end{array}$ & \pm & \\
\hline & & 6 & 42 & + & \\
\hline & & 6 & 120 & - & \\
\hline & \multirow{7}{*}{$\begin{array}{l}\text { Carcinoma } \\
\text { of uterine } \\
\text { corpus }\end{array}$} & 12 & 13 & + & \multirow{7}{*}{$\begin{array}{ll}S \cdot H & (101) \\
S \cdot M & (87)\end{array}$} \\
\hline & & $\begin{array}{r}3 \\
37\end{array}$ & $\begin{array}{l}16 \\
95\end{array}$ & \pm & \\
\hline & & $\begin{array}{r}5 \\
40\end{array}$ & $\begin{array}{l}29 \\
80\end{array}$ & \pm & \\
\hline & & 10 & 58 & + & \\
\hline & & 6 & 99 & - & \\
\hline & & 1 & 19 & + & \\
\hline & & 3 & 62 & + & \\
\hline & \multirow{7}{*}{$\begin{array}{l}\text { Carcinoma } \\
\text { of uterine } \\
\text { cervix }\end{array}$} & 1 & 72 & + & \multirow{7}{*}{$\begin{array}{l}\mathrm{T} \cdot \mathrm{H}_{1}(94) \\
\mathrm{S} \cdot \mathrm{H}(78)\end{array}$} \\
\hline & & $\begin{array}{r}4 \\
27\end{array}$ & $\begin{array}{l}38 \\
77\end{array}$ & \pm & \\
\hline & & $\begin{array}{r}6 \\
43\end{array}$ & $\begin{array}{l}158 \\
113\end{array}$ & $=$ & \\
\hline & & 3 & 77 & - & \\
\hline & & 6 & 21 & + & \\
\hline & & $\begin{array}{r}4 b \\
9\end{array}$ & $\begin{array}{r}106 \\
73\end{array}$ & + & \\
\hline & & & 10 & + & \\
\hline
\end{tabular}


tion from 73 patients with gynecologic tumors, including 6 ovarial carcinomas, 6 carcinomas of cervix, 7 endometrial carcinomas, 10 choriocarcinomas, 5 invasive moles, 33 hydatidiform moles and 6 uterine myomas who have received surgical operation. The clinical diagnosis was confirmed in every case by histological examination of the tumor tissue removed from these patients.

In the beginning, twenty-nine patients with gynecologic malignant tumor were studied immediately after extirpation of pathology in the migration test. The inhibition of macrophage migration occured in 25 cases: 5 out of 6 ovarial carcinomas, 4 out of 6 carcinomas of cervix, 6 out of 7 endometrial

\section{Table $\$$}

Result of migration inhibition test in patients with choriocarcinoma and uterine myoma after operation

\begin{tabular}{|c|c|c|c|c|c|}
\hline Patient & Tumor type & $\begin{array}{l}\text { Time after } \\
\text { operation } \\
\text { (days) }\end{array}$ & $\begin{array}{c}\text { Migration } \\
\text { index with } \\
\text { autochthon- } \\
\text { ous tumor } \\
(\%)\end{array}$ & Reaction & $\begin{array}{l}\text { Migration } \\
\text { index with } \\
\text { allogeneic } \\
\text { tumor } \\
(\%)\end{array}$ \\
\hline & \multirow{10}{*}{$\begin{array}{l}\text { Chorio- } \\
\text { carcinoma }\end{array}$} & 84 & $\begin{array}{l}55 \\
26\end{array}$ & + & \multirow[t]{4}{*}{$A \cdot S(122)$} \\
\hline & & $\begin{array}{l}17 \\
71\end{array}$ & $\begin{array}{r}57 \\
115\end{array}$ & \pm & \\
\hline & & $\begin{array}{r}8 \\
47 \\
151\end{array}$ & $\begin{array}{l}60 \\
60 \\
57\end{array}$ & + & \\
\hline & & $\begin{array}{r}1 \\
15\end{array}$ & $\begin{array}{l}30 \\
91\end{array}$ & \pm & \\
\hline & & $\begin{array}{l}1 \\
35 \\
98\end{array}$ & $\begin{array}{l}29 \\
20 \\
14\end{array}$ & + & \multirow[t]{2}{*}{$Y \cdot K(177)$} \\
\hline & & $\begin{array}{l}1 \\
28\end{array}$ & $\begin{array}{l}55 \\
78\end{array}$ & \pm & \\
\hline & & $\begin{array}{r}3 \\
37\end{array}$ & $\begin{array}{r}57 \\
139\end{array}$ & \pm & \multirow[t]{2}{*}{$\mathrm{K} \cdot \mathrm{I} \quad(126)$} \\
\hline & & $\begin{array}{l}12 \\
69\end{array}$ & $\begin{array}{r}10 \\
104\end{array}$ & \pm & \\
\hline & & $\begin{array}{r}13 \\
153\end{array}$ & $\begin{array}{l}65 \\
10\end{array}$ & \pm & $Y \cdot I \quad(114)$ \\
\hline & & $\begin{array}{l}12 \\
35\end{array}$ & $\begin{array}{r}39 \\
158\end{array}$ & \pm & $\mathrm{H} \cdot \mathrm{K}(82)$ \\
\hline & \multirow{6}{*}{$\begin{array}{l}\text { Uterine } \\
\text { myoma }\end{array}$} & 6 & 98 & - & \\
\hline & & 6 & 110 & - & \\
\hline & & 1 & 130 & - & \\
\hline & & 6 & 126 & - & \\
\hline & & 1 & 109 & - & \\
\hline & & 1 & 103 & - & \\
\hline
\end{tabular}


carcinomas and 10 out of 10 choriocarcinomas. The m. M.I ranged from 10 to 73 per cent $(42.6 \pm 18.4)$. The six benign tumor patients with uterine myoma showed no inhibition of macrophage migration as tested immediately after operation. The m. M.I. was $112.7 \pm 11.6$ and the difference between benign and malignant tumor was statistically significant (Student's $t$ test, $t=13.226$ $\mathrm{p}<0.001)$.

These data of migration tests were summarized in Table 2, 3 and Fig. 2 shows the distribution of the modified migration indices from twenty-nine patients with malignant tumor and six with benign tumor. These results suggest that host response to malignant tumor may be mediated by the cellular immune mechanism and only the malignant tumor may have antigenicity in this mechanism. However, the tumors of four patients, 2 carcinomas of cervix, one ovarial and endometrial carcinoma, showed no inhibition of migration in the test.

When malignant tumors obtained from other patients as antigen were employed in the migration system, positive reactions to the antigens were not observed in all situations (Table 2,3). This result suggests that no cross reactions were found with tumor antigens from other patients in human gyne-

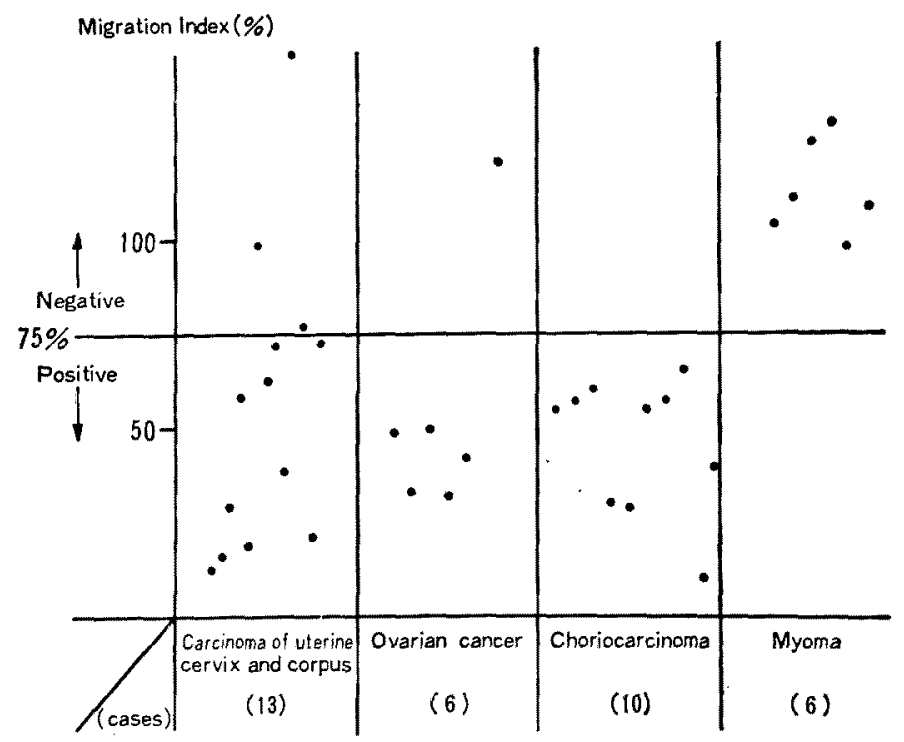

Fig. 2. Macrophage migration inhibition test in gynecologic tumors. 
cologic malignant tumors. In a patient with endometrial carcinoma, migration inhibitory activity was not also detected in autologous tumor-free tissue removed from same patient who has taken the result of positive response with her tumor antigen. (M.T.)

Out of 16 patients who have shown positive migration inhibitory activity in the initial test, 12 cases recieved complete extirpation of pathology and disclosed negative reaction between 35 to 60 days after the operation. The reaction of four patients with wide spread metastasis remained positive for 84 to 153 days after operation. Three of them afterward were confirmed dead with metastatic choriocarcinoma in spite of the strong treatment by chemotherapy, but the other still survived without any clinical findings for 20 month after the last test. In addition, it was proved that a patient died 19 months after operation while the reaction has continued being positive though she was clinically well.

The data of degree of migration inhibition in postoperative period, can be seen from Table 2, 3 in detail and Fig. 3 demonstrates graphically the time course of the value of the migration inhibition.

Next, cell mediated immunity to tumor associated antigens was also measured in 5 patients with invasive mole and 33 with hydatidiform mole immediately after operation with the use of MIT system.

Four out of five patients with invasive mole showed no significant inhibition of migration (m. M.I was $101.8 \pm 17.7 \%$ ) and migration indices in 33 patients

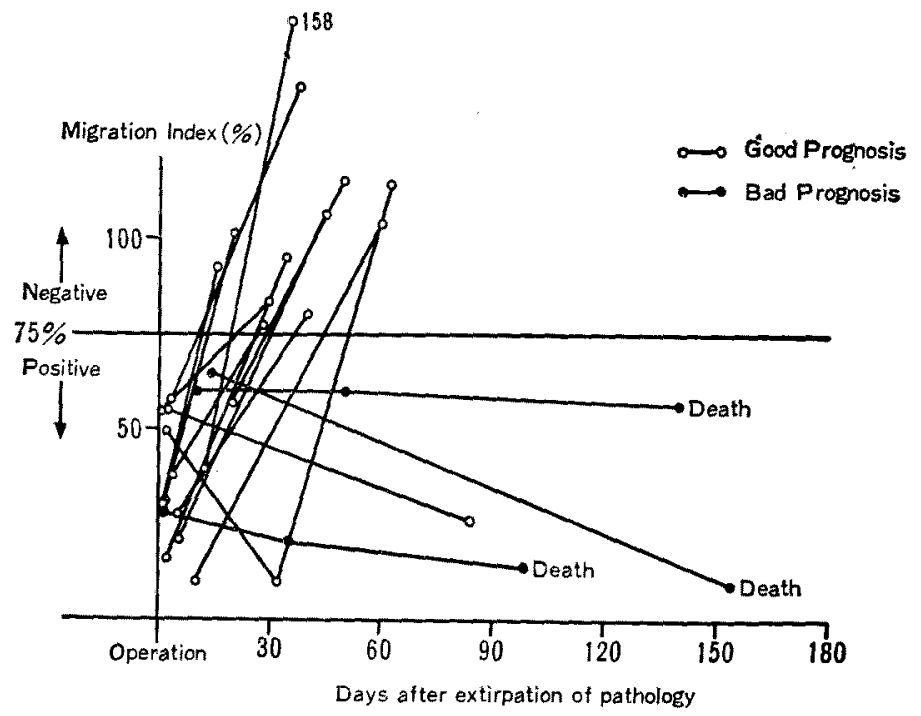

Fig. 3. Migration inhibitory activity pattern after operation in patients with malignant tumors. 


\section{Table \&}

Frequency of significant inhibition of macrophage migration from patients with trophoblastic disease immediately after operation

\begin{tabular}{|c|c|c|c|}
\hline \multirow{2}{*}{$\begin{array}{c}\text { Clinical } \\
\text { diagnosis }\end{array}$} & \multirow{2}{*}{$\begin{array}{l}\text { No. of positive } \\
\text { patients/no. of } \\
\text { patients tested }\end{array}$} & \multicolumn{2}{|c|}{ Migration index } \\
\hline & & $\%$ & Mean \pm SD $\%$ \\
\hline Choriocarcinoma & $10 / 10$ & 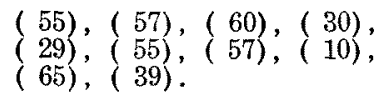 & $45.7 \pm 16.9$ \\
\hline Invasive mole & $1 / 5$ & $\begin{array}{l}(94),(110),(73),(126), \\
(106) .\end{array}$ & $101.8 \pm 17.7$ \\
\hline \multirow[b]{2}{*}{$\begin{array}{l}\text { Hydatidiform } \\
\text { mole }\end{array}$} & \multirow[b]{2}{*}{$11 / 33$} & 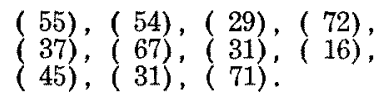 & $\begin{array}{l}\text { Positive } \\
46.2 \pm 18.1\end{array}$ \\
\hline & & $\begin{array}{l}(81),(93),(132), \quad(92), \\
(123),(152), \quad(79), \quad(104), \\
(145),(85), \quad(81),(166), \\
(101), \quad(69), \quad(89), \quad(96), \\
99),(150), \quad(162), \quad(100), \\
(108),(107) .\end{array}$ & $\begin{array}{l}\text { Negative } \\
109.7 \pm 28.3\end{array}$ \\
\hline
\end{tabular}

with hydatidiform mole varied widely from 16 to 166 per cent and are divided into two groups. Eleven of them showed positive response and the rest negative and the m. M.I were $46.2 \pm 18.1,109.7 \pm 28.3 \%$ respectively (Table 4 ).

It was also observed that seven out of 8 patients in positive group who could be followed up after curretage had been to receive chemotherapy after a time. Table 4 illustrates the frequency of positive migration inhibition from patients with choriocarcinoma, invasive mole and hydatidiform mole and these were 100,20 and $33 \%$ respectively.

This result suggests that there are difference between tumor-antigen of choriocarcinoma and invasive mole.

\section{DISCUSSION}

Recently, the light has been thrown upon cellular immunity which is the vector of the immune defense mechanism most likely to be capable of inhibiting tumor growth. This search has therefore made for evidence of tumor specific cellular immunity in patients with various types of gynecologic tumor. Present experiments done with the macrophage migration inhibition test, demonstrated that $86 \%$ out of 29 patients with malignant tumor revealed positive migration inhibitory activity immediately after extirpation of pathology and reversely, patients with benign tumor (uterine myoma) showed no significant inhibition 
of macrophage migration. This research provided convincing evidence for the existence of tumor specific antigens and a corresponding cellular immune response for a variety of human malignant tumor.

Chu et al24 studied the reactivity of human lymphocytes against autochthonous and allogeneic nasopharyngeal neoplastic cells. Hellström et al, ${ }^{3}$ using colony inhibition technique, have demonstrated in vitro destruction of certain tumor cells by the patient's own lymphoid cells. These findings were interpreted as indicating the existence of tumor specific antigens and occurrence of tumor distinctive cellular immunity. The results in my present studies confirmed these observations.

In tumor bearing mice, MIT has been also examined with autochthonous or syngeneic tumor antigens. Migration inhibitory activity has not been detected only in most mice when tested with autochthonous tumor antigen but also detected in some cases where done with syngeneic tumor antigen. This result suggests that cross reactions were found in syngeneic system. On the other hand there was no sign of crossreactivity between tumor associated antigens obtained from other patients with various types of human malignant tumor. The first result has been confirmed by those of Morton et al, ${ }^{25}$ previously published. The latter finding was, however, contrary to that of Bubenik et al ${ }^{26}$ and Freedman et al. ${ }^{27}$

It seems paticularly interesting in prophylactic aspect that cross reactions detected with many groups of neoplasms suggest the theoretical possibility of immunization against tumors belonging to such group when common antigens are found between human neoplasms.

Akiyama et al ${ }^{28}$ reported, using MIT for detecting cellular immunity against tumors in mice to which rat ascites hepatoma was injected xenogenically, that early appearance of the migration inhibitory activity while grafted tumor cells were replicating and its rapid disappearance after complete rejection of the tumor cells were observed. Present experiments which were based on the results by Akiyama et al, showed that 12 out of 16 patients with malignant gynecologic tumor who were followed up received complete extirpation of pathology and disclosed negative reaction between 35 to 60 days after operation. This work also illustrated that the reaction of 3 other patients who died afterward, remained positive for a long time. The results presented herein confirmed the informations by Akiyama et al.

In most recent publications, Hellström et $a l^{29}$ and Sjögren et a ${ }^{30}$ demonstrated in the sera of tumor bearers the presence of blocking antibodies, which were, according to these authors, responsible for the abrogation of the specific inhibitory activity of otherwise reactive lymphocytes in vitro test. They might act 
either by suppressing the activity of sensitized effector cells or by coating and inactivating the antigen sites on the target tumor cell surface. Since it was interesting to extend this concept. The study in the mechanism of this phenomenon are in progress.

It has been generally known that the development of trophoblastic disease will have relation to immunological attitude. Skin transplantation from husband was performed on five patients with choriocarcinoma and on two with hydatidiform mole by Robinson et al.31 In four patients with metastatic spread of choriocarcinoma, prolonged survival graft from the husbands were found. It was observed that the husband's skingrafts on two patients with hydatidiform mole were rejected after 10-14 days as well as skingrafts from normal donors transplanted to the patients were rejected after 10 to 15 days.

The study on trophoblastic disease with the use of MIT is the first attempt in this experiment. The frequency of positive migration inhibition from patients with choriocarcinoma, invasive mole and hydatidiform mole were 100, 20 and 33 per cent. The result on the choriocarcinomas agreed with one reported by Robinson et al, using spouse's skingraft technique. In addition the author observed that the reaction in hydatidiform mole are divided in two groups. Some patients who showed positive response in the initial test, needed to receive chemotherapy after a time. More immunological observations are necessary to explain these tumor growths, spontaneous regression and the development to choriocarcinoma of hydatidiform mole.

In conclusion, the author can confirm the presence of cellular immunity in the patients and animals bearing malignant tumor by using MIT. This may also apply that MIT used clinically can be instrumental to evaluate various therapeutic means of malignant neoplasms.

\section{ACKNOWLEDGEMENT}

The author wishes to express her gratitude of Professor Yukio Notake, Keio University, for his helpful advice and stimulating critism and to Professor Takehisa Akiyama, Dep. Microbiol., Kitasato University, for valuable suggestions and encouragement during the course of the work. Author's gratitude is also extended to Assistant Professor Shozo Tamura, Keio Univ., for his help in preparing this manuscript and stimulating discussion. In addition, special thanks are given to the members of the first laboratory, Dep. Obstet. Gynec., Keio Univ., for their support and advice during the investigation.

\section{REFERENCES}

1. Mathe', G.: Immunological studies in patients with placental choriocarcinoma. J. 
Natl. Cancer Inst. 33: 193-208, 1964

2. Sjögren, H. O.: Transplantation methods as a tool for detection of tumor specific antigens. Prog. Exp. Tumor. Res. 6: 289-322, 1965

3. Hellström, I., Hellström, K. E., Pierce, G. E. and Yang, J. P. S.: Cellular and humoral immunity to different types of human neoplasms. Nature $220: 1352-1354$, 1968

4. Prehn, R. T. and Main, J. M.: Immunity to methylcholanthrene induced sarcomas. J. Natl. Cancer Inst. 18: 769-778, 1957

5. Amos, D. B.: Possible relationships between the cytotoxic effects of isoantibody and host cell function. Ann. N.Y. Acad. Sci. 87: 273-292, 1960

6. Allison, A. C.: Immune responses to shope fibroma virus in adult and newborn rabbits. J. Natl. Cancer Inst. 36: 869-876, 1966

7. Graham, J. B. and Graham, R. M.: Tolerance agent in human cancer, Surg. Gyn. Obst. 118: 1217-1222, 1964

8. Klein, E. and Sjögren, H. O.: Humoral and cellular factors in homograft and isograft immunity against sarcoma cells. Cancer Res. 20: 452-461, 1960

9. Rosenau, W. and Moon, H. D.: Lysis of homologous cells by sensitized lymphocytes in tissue culture. J. Natl. Cancer Inst. 27: 471-477, 1961

10. Brunner, K. T., Manel, J., Cerottini, J. C. and Chapris, B.: Quantitative assay of the lytic action of immune lymphoid cells on $51 \mathrm{Cr}$-labelled allogeneic target cells in vitro; Inhibition by isoantibody and by drugs. Immunology 14:181-196, 1968

11. Wolberg, W. H. and Goelzer, M. L.: In vitro assay of cell mediated immunity in human cancer; Difinition of leukocyte migration inhibitory factor. Nature 229: $632-634,1971$

12. David, J. R., Lawrence, H. S. and Thomas, L.: Delayed hypersensitivity in vitro; III. The specificity of hapten-protein conjugations in the inhibition of cell migration. J. Immunol. 93: 279-282, 1964

13. Bloom, B. R. and Bennett, B.: Mechanism of a reaction in vitro associated with delayed-type hypersensitivity. Science 153: 80-82, 1966

14. Bennett, B. and Bloom, B. R.: Reactions in vivo and in vitro produced by a soluble substance associated with delayed type hypersensitivity. Proc. Natl. Acad. Sci. U.S.A. 59: $756-762,1968$

15. Moini, R. N., Bryceson, A. B. M., Wolstencroft, R. A. and Dumonde, D. C.: Lymphocytes mitogenic factor in man. Nature 224: 43-44, 1969

16. Dumonde, D. C.: The role of the macrophage in D. H. British Medical Bulletin 23: 9-14, 1967

17. Ward, P. A., Remold, H. G. and David, J. R.: Leucotactic factor produced by sensitised lymphocytes. Science 163: 1079-1081, 1969

18. Green, J. A., Cooperband, S. R. and Kibrick, S.: Immune specific induction of interferon production by cultures of human blood lymphocytes, Science 164: 14151417,1969

19. Remold, H. G. and David, J. R.: Cellular hypersensitivity; Characterization of migration inhibitory factor (MIF) by enzymatic treatment. Fed. Proc. 29: 305 abs., 1970

20. Thor, D., Juresis, R. E., Veach, S. R., Miller, E. and Dray, S.: Cell migration inhibition factor released by antigen from human peripheral lymphocytes. Nature 219: 755-757, 1968

21. Medzihradsky, $J$. and Kalafut, F.: Inhibition migration of peritoneal exudate cells harvested from rats bearing syngeneic or autochthonous tumors. Neoplasma 19: $147-149,1972$

22. Vaage, J., David, J. and Barry, W. B.: Tumor-specific resistance in mice detected by inhibition of macrophage migration. Cancer Res. 32: 680-687, 1972.

23. Murphy, E. D.: Studies on carcinogen-induced carcinoma of the cervix in mice. 
Am. J. Path. 29: 608, abs., 1953

24. Chu, E. H., Stjernsward, J., Clifford, P. and Klein, G.: Reactivity of human lymphocytes against autochthonous and allogeneic normal and tumor cells in vitro. J. Natl. Cancer Inst. 35: 595-617, 1967

25. Morton, D. L., Malmgren, R. A., Hall, W. J. and Schidlovsky, G.: Immunologic and virus studies with human sarcomas. Surgery $66: 152-162,1969$

26. Bubenik, J., Perlman, P., Helmstein, K. and Moberger, G.: Immune response to urinary bladder tumors in man. Int. J. Cancer 5: 39-46, 1970

27. Freedman, S. O., Gold, P., Krupey, J. and Machado, H. D. C.: Human tumor antigens. Proc. Eighth Canadian Cancer conference 407-424, 1969

28. Akiyama, T., Yamaura, N., Kenjo, T., Ohmura, T. and Matsuda, R.: Macrophage migration inhibition test-Experimental and clinical studies. Keio J. Med. 20: 15-27, 1971

29. Hellström, I., Sjögren, H. O., Warner, G. and Hellström, K. E.: Blocking of cellmediated tumor immunity by sera from patients with growing neoplasms. Int. J. Cancer 7: 226-237, 1971

30. Sjögren, H. O., Hellström, I., Bansal, S. C. and Hellström, K. E.: Suggestive evidence that the Blocking antibodies of tumor-bearing individuals. Acad. Sci. (Wash) 68: 1372-1375, 1971

31. Robinson, E., Ben-Hur, N., Zuckerman, H. and Neuman, Z.: Further immunologic studies in patients with choriocarcinoma and hydatidiform mole. Cancer Res. 27: 1202-1204, 1967 